\title{
SoTL Lab: Undergraduate student-faculty collaborative research in teaching and learning in CSD
}

\author{
Lian J. Arzbecker \\ University of Wisconsin - Eau Claire, arzbeclj@uwec.edu \\ Ellen A. Blacklock \\ University of Wisconsin - Eau Claire, blackle@uwec.edu \\ Ashley M. Crumb \\ University of Wisconsin - Eau Claire, crumbam@uwec.edu
}

See next page for additional authors

DOI: doi.org/10.30707/TLCSD2.2Arzbecker

Follow this and additional works at: https://ir.library.illinoisstate.edu/tlcsd

Part of the Scholarship of Teaching and Learning Commons

\section{Recommended Citation}

Arzbecker, Lian J.; Blacklock, Ellen A.; Crumb, Ashley M.; Doyle, Jordan D.; Esveld, Mariana; Grelson, Sophie L.; Gretzinger, Beatrice; Korpela, Alyse; Kressin, Kayley A.; Pakanich, Lauren M.; Pulley, Torri L.; Nolte Rierdon, Nicole L.; Spreitzer, Kathleen A.; Steines, Emma L.; Strom, Brittany J.; Symons, Emily C.; Vogelsang, Megan; Vruwink, Olivia N.; Weberg, Kelsey L.; Wolosek, Ashley B.; Zigler, Erin D.; Hoepner, Jerry K.; Hemmerich, Abby L.; Sather, Tom W.; and Elledge, Deborah H. (2018) "SoTL Lab: Undergraduate student-faculty collaborative research in teaching and learning in CSD," Teaching and Learning in Communication Sciences \& Disorders: Vol. 2: Iss. 2, Article 8.

DOI: doi.org/10.30707/TLCSD2.2Arzbecker

Available at: https://ir.library.illinoisstate.edu/tlcsd/vol2/iss2/8

This Student Voices is brought to you for free and open access by ISU ReD: Research and eData. It has been accepted for inclusion in Teaching and Learning in Communication Sciences \& Disorders by an authorized editor of ISU ReD: Research and eData. For more information, please contact ISUReD@ilstu.edu. 


\title{
SoTL Lab: Undergraduate student-faculty collaborative research in teaching and learning in CSD
}

\author{
Abstract \\ The University of Wisconsin-Eau Claire Communication Sciences and Disorders SoTL Lab was designed \\ to provide hands-on research experiences to undergraduate students on a large scale. Student reflections \\ on experiences within the SoTL Lab identify the value of collaboration, development of confidence, and \\ exposure to the entire research process as key outcomes. These experiences foster development of \\ research skills and may lead students to consider academic careers.

\section{Keywords} \\ undergraduate research, reflection, research lab

\section{Cover Page Footnote} \\ The University of Wisconsin-Eau Claire SoTL Lab would like to acknowledge the ongoing support from the \\ department. We would like to acknowledge the work of past SoTL Lab students who help to define, \\ develop, and hone the principles of this collaborative endeavor.

\section{Authors} \\ Lian J. Arzbecker, Ellen A. Blacklock, Ashley M. Crumb, Jordan D. Doyle, Mariana Esveld, Sophie L. \\ Grelson, Beatrice Gretzinger, Alyse Korpela, Kayley A. Kressin, Lauren M. Pakanich, Torri L. Pulley, Nicole L. \\ Nolte Rierdon, Kathleen A. Spreitzer, Emma L. Steines, Brittany J. Strom, Emily C. Symons, Megan \\ Vogelsang, Olivia N. Vruwink, Kelsey L. Weberg, Ashley B. Wolosek, Erin D. Zigler, Jerry K. Hoepner, Abby L. \\ Hemmerich, Tom W. Sather, and Deborah H. Elledge
}


The University of Wisconsin-Eau Claire Communication Sciences and Disorders (CSD) Scholarship of Teaching and Learning (SoTL) Lab was developed to engage undergraduate students in true collaborative research about teaching and learning. Since its inception three years ago, the research lab has engaged approximately 20 undergraduate students per year. Initially, three faculty were involved in collaboration and mentoring. Presently, five faculty are engaged on a weekly basis. The lab meets each Friday morning for two hours in a large active learning room. Students work in teams of two to three, collaborating with one or two primary faculty mentors. While a primary faculty advisor works with each student team, students receive support and feedback from all faculty mentors depending upon areas of methodological expertise or the nature of the support needed. Students are engaged in every aspect of the research process from literature searching, institutional review board application, methodology design, recruitment, data collection, data analysis, and interpretations. Further, students are co-authors in research presentations and publications. The purpose of this reflection paper is to provide the students' perspective on their research experiences within the lab.

\section{Impetus for undergraduate student-faculty collaborative research}

The American Speech-Language-Hearing Association (ASHA) Joint Ad Hoc Committee on the Shortage of PhD Students and Faculty in CSD identified a major shortage of doctoral-trained faculty in CSD programs (ASHA, 2002). The Academic Affairs Board released a report in 2013, identifying an ongoing deficit and a strategic plan to address these concerns (ASHA, 2013). This issue is pertinent to the training of future clinicians and researchers. Committee recommendations included: 1) a revised undergraduate curriculum to increase rigor and exposure to academic careers, and 2) providing opportunities for students at all levels of professional preparation to receive greater exposure to research experiences, along with clinical training. Research experiences, like those provided through the SoTL Lab, have a potential to strengthen disciplinary knowledge and applied research experience.

Exposure to undergraduate research has positive influences on retention, performance, and perspectives on the value of research. The National Survey of Student Engagement (NSSE) examines undergraduate student performance across extracurricular experience, high-impact practices (including research), and course-based learning (Kuh, 2009). Along with better rates of retention in programs, students who have engaged in research perform better in subsequent academics (Kuh, 2009).

ASHA (2005) defines evidence-based practice through a triad of elements: research evidence, clinical expertise, and patient values. ASHA standard III-F requires knowledge of the research process and an ability to implement research principles into clinical practice. Nail-Chiwetalu and Berstein-Ratner (2007) identified the development of information literacy skills to effectively access and employ best practices as a critical need for training students.

\section{Faculty perspectives on student reflections}

Twenty-one students involved in SoTL Lab completed reflections on their collaborative research experiences at the end of a year-long experience. As faculty mentors, we want to highlight the following three principles that emerged from the reflections and were established through SoTL 
lab: 1) organizational structure provides access to peer and faculty mentors on a regular basis, 2) exposure to a systematic lab focused on student learning dispels misconceptions about the exclusivity of who can conduct research and related mindsets that undermine student's selfperceptions about their ability to engage in research, and 3) students value and benefit from a start to finish experience, including all elements of the research process, as opposed to performing menial, tedious tasks.

\section{Student reflections}

Organizational accessibility. The SoTL Lab allows research teams to work together weekly in an active learning classroom, a structure that provides access to peers and faculty mentors while facilitating collaborative work. Students discuss the value of this organization.

P10. Through SoTL lab I furthered my knowledge of research through working with faculty. Having access to faculty mentors allowed me to continuously work on my research because during lab as I was writing I had direct access to faculty to ask questions as they arose. Additionally, I got to work with other faculty members and get their perspective on my research. This was helpful because I had the opportunity to collaborate with a number of faculty, which furthered my knowledge of research.

P6. I had a great experience working with the faculty on my research. They were very helpful and guided me through the research process. I felt like I was a part of a collaborative team and we worked well together. Inever felt alone in the process and my questions were answered thoroughly.

P11. I am very grateful for the opportunity to join the SoTL lab. Being a part of the SoTL lab really helped motivate my own research. I really enjoyed coming and hearing about other people's projects and seeing what they are doing. Research can sometimes be overwhelming, and having so many people working through research together at the same time was really beneficial. It was inspiring and encouraging to see so many people finishing their research projects and to be able to present their work. I also enjoyed having the opportunity to share what I am doing on my research project with others. It helped me to think more about my research as well as begin to more explicitly describe components of it that might not have been as clear previously. In addition, having faculty here as resources helped me to get lingering questions answered and stay on track with my research project.

I have really enjoyed the experiences with student-faculty collaborative research. One aspect I really enjoyed about SoTL lab is that not only is your specific faculty mentor present, but multiple faculty members are present and they are all very willing to provide support and answer questions. I have been able to pull from the backgrounds of multiple different faculty members to assist my research through attending SoTL lab. I also found it beneficial to talk about my research with a faculty member who wasn't as familiar with my research because it really pushed me to think through certain parts more and to become better at summarizing components of my research. I am really looking forward to continuing to be pushed through SoTL lab and to increase skills in both writing and discussing research. 
P8. Having the time set aside to meet with other researchers and faculty is extremely beneficial. I can't imagine doing this project as well as we did without this time set aside.

P14. I really appreciated having a work environment conducive to working minds. All the students coming together and collaborating ideas off of one another is such an amazing process to be a part of. Although we were all on different projects, it felt like a family when we came together in the research room. I loved creating relationship with the professors and the other students that participated in research.

Dispelling misconceptions and altering mindsets. The SoTL Lab pairs students and faculty as co-investigators in the research process. This serves as an apprenticeship model for learning and implementing a complex process. Students reflect on the way this structure decreases intimidation and facilitates self-efficacy.

P5. I have had a very positive and eye-opening experience in the SoTL lab this past academic year. I have learned so much about the research process and successful ways to present research as well. I never knew how specific and meticulous I had to be with my language when writing the IRB and other forms that we submitted for our project. Though I had to write multiple drafts and edit my documents a few times, it felt so rewarding to produce a complete and cohesive research document. I have also become a lot more confident in my skills communicating my research to others.

P9. Prior to joining the SoTL Lab, I had minimal research experience and assumed that research was reserved for an exclusive group. However, the Lab environment was extremely welcoming and provided me with numerous opportunities to practice my academic skills. By working in conjunction with faculty members and fellow students, I discovered the importance of collaboration. The Lab provided a unique environment - experienced researchers were paired with newer students - which naturally fostered mentoring amongst members. Working directly with faculty was as helpful as it was encouraging; student-professor project teamwork is very different than regular classroom interactions, and I appreciated the collaborative dynamic. The mentoring relationships that were fostered will extend into the rest of my time as a student, and into my future career. Perhaps the greatest benefit I have received from participating in the Lab is realizing my passion for research. Although I am still quite new to the research process, I am excited to continue work in this area.

P4: This increased my self-efficacy related to research holistically and made me much more motivated and confident as an independent learner.

P12. Working with the faculty through the SoTL lab has been an awesome experience. They have allowed me to conduct an entire research project with another undergraduate student with their supervision. I've learned not to be afraid of research, but to look at it as a challenge. When I came to college I didn't want to participate in any research because I thought it was too intimidating. But, working in the SoTL lab has exposed me to research in a positive way. I've had the opportunity to spend a year conducting a research project on a topic that is important to me. If I hadn't had the experience within the SoTL lab I may have gone onto graduate school with the same negative view of research that I came into my undergraduate 
with. Now, I'm excited to continue to conduct research at the graduate level and possibly beyond.

P1: Knowing how to complete research and having a drive to ask questions can help students in any future research or in their careers.

P13. Being a sophomore and starting a research project was at first daunting. I did not have a great idea of what a whole research study entailed. Doing a project in a research class and doing a real research study are a lot different. But reflecting upon my experience, I really enjoyed the SoTL Lab environment.

Start to finish. Students participate in each step of the process including literature review, IRB, research design, recruitment, data collection, data analysis and interpretation. Because students work in collaboration with peers and faculty mentors, they are guided through each of these elements, rather than left to struggle through those complex processes independently.

P7. I got to start a project, develop my questions/hypothesis, find previous research, develop my methodology, analyze the data, develop preliminary findings, and present my findings to multiple audiences. This entire project helped me to recognize all the different skills required for the research project, including critical thinking skills, organizational skills, writing skills, etc. I personally think that I can take these skills and apply them to my future education and clinical career.

P15. For the entire first semester, I can confidently say that I had no idea what I was doing or where the project was exactly going. My research partner and I were coding reflections and calculating numbers that we weren't sure what we were going to do with. We often joked that we were in a fog and that some point we would have to see the light at the end of the tunnel. Slowly but surely, we began to see that light as every number and coded reflection began to take shape into what we wanted our project to become. Even after all the coding, writing and creating a poster, it wasn't until we presented our findings that everything clicked in my mind.

P3. Each week is motivational and academically beneficial. The tiny room is filled with many determined students striving to develop their academic understanding and familiarize themselves with the research process.

P16. One of my big takeaways from the SoTL research is that research is always changing and evolving therefore it is important to search for answers and use the practices that have been proven effective. I have also learned that persistence is key, because even when a task seems too big, or when it feels like there is no light at the end of the tunnel, eventually it all works out in the end.

P2. Through the process of talking about our research, I felt as if I expanded upon my own knowledge about the topic. I realized how valuable the research that we have conducted can be for not only the CSD department, but also teaching in general. 


\section{Implications}

The SoTL Lab model addresses information literacy, understanding of research design, and the ability to interpret research that put students in a position to employ evidence-based practice and consider careers in academia. These student reflections illustrate the depth and breadth of learning within this context. The following list includes potential implications of this experience:

1. Successful engagement in research fosters interest in considering doctoral programs

2. Undergraduate research serves as a gateway for graduate research and academic careers

3. Hands-on exposure to the research process reduces intimidation and increases self-efficacy

4. Hands-on exposure to the research process increases information literacy and ability to consume/implement evidence-based practice

5. Peer mentoring fosters a culture of sharing and joint problem solving

6. Accessibility and feasibility of SoTL research allows undergraduate students to complete the entire process

7. Hands-on experience in research fosters self-regulated learning in other contexts

8. Lab structure makes multiple student projects feasible, efficient, and productive

\section{References}

American Speech-Language-Hearing Association. (2002). Crisis in the discipline: a plan for reshaping our future. American Speech-Language-Hearing Association and Council of Academic Programs in Communication Sciences and Disorders: Report of the joint ad hoc committee on the shortage of PhD students and faculty in communication sciences and disorders. Retrieved from https://www.asha.org/uploadedFiles/academic/reports/CrisisInTheDiscipline.pdf.

American Speech-Language-Hearing Association. (2005). Evidence-based practice in communication disorders [Position statement]. Retrieved from http://www.asha.org/members/ deskref-journals/deskref/default.

American Speech-Language Hearing Association. (2013). Strategic plan to increase the student pipeline and workforce for PhD researchers and faculty researchers: Report of the Academic Affairs Board. Retrieved from https://www.asha.org/uploadedFiles/Report2013-AAB-PhD-Report-Strategic-Plan.pdf

Kuh, G.D. (2009). The National Survey of Student Engagement: Conceptual and Empirical Foundations. New Directions for Institutional Research, 141, 5-20. DOI:10.1002/ir.283

Nail-Chiwetalu, B., \& Bernstein-Ratner, N. (2007). An assessment of the information-seeking abilities and needs of practicing speech-language pathologists. Journal of the Medical Library Association, 95(2), 182. 